\title{
Laughing at Unbearable Urges: Reshaping the Male-Authored Script of Desire
}

DORA E. POLACHEK

Binghamton University, State University of New York (SUNY)

\begin{abstract}
As Pierre Champion noted a half a century ago, "The Cent Nouvelles nouvelles open a secret door into the house of men of that time." The misogynous aspect of these novellas, designed to inspire laughter, is evident in most of the stories dealing with masculine drives and uncontrollable desires of husbands to seduce other women without being discovered. Novella 9 is a prime example of such a scenario, a novella that serves as Marguerite de Navarre's intertext in the Heptaméron's novella 8. In this article I will analyze how Marguerite reshapes her fifteenth-century intertext in order to promote a highly protofeminist agenda. All the while maintaining the same structure and characters, she introduces changes that are both subtle and radical. The focus of my analysis will show how these changes put into question the masculinist vision offered by CNN 9 and open instead a space for a commentary on women's agency and their quest for their own pleasure.
\end{abstract}

Comme Pierre Champion l'a remarqué il y a 50 ans, "Les Cent nouvelles nouvelles ouvrent ... une porte secrète de la maison des hommes de ce temps". Laspect misogyne de ces nouvelles destinées à faire rire est évident dans la plupart des nouvelles, où il s'agit des pulsions masculines et du désir incontrôlable de la part d'un mari volage de séduire une autre femme sans en être découvert. Telle est la situation dans la nouvelle 9 de cette collection, nouvelle qui sert comme intertexte de la nouvelle 8 de L'Heptaméron. Dans cet article je vais analyser comment Marguerite remanie cette nouvelle $d u X V$ siècle afin de promouvoir ses idées protoféministes. Tout en gardant la même structure et les mêmes personnages, Marguerite introduit des changements à la fois subtils et radicaux, changements qui remettent en question la vision masculiniste offerte dans CNN 9 et ouvre un espace pour un commentaire sur la prise de parole de la femme à la recherche de son propre plaisir.

s the 2014 MLA international bibliography indicates, between 1992
Marguerite de Navarre's birth - there were more critical works published about
Marguerite's Heptaméron (about 430) than in the entire time span covered in
H. P. Clive's 1983 bibliography of everything published on the Heptaméron
from its creation to almost five hundred years later. ${ }^{1}$ Among the recent
publications, Colette Winn's Approaches to Teaching Marguerite de Navarre's
Heptameron made at least two things clear: first, that Marguerite's work had

1. H. P. Clive, Marguerite de Navarre: An Annotated Bibliography (London: Grant \& Cutler, 1983).

Renaissance and Reformation / Renaissance et Réforme 38.3, Summer / été 2015 
reached canonical status, and second, that this Approaches volume responded to a need expressed by those teaching or interested in teaching the work, who welcomed the theoretical and critical readings as well as the pedagogical tools and strategies that the contributors offered in those pages. ${ }^{2}$ Given the trajectory already firmly established in Heptaméron studies, one can only imagine what new paths will be explored as we and newer colleagues approach future marker years such as 2049 (five-hundredth anniversary of Marguerite's death) or 2058 (five-hundredth anniversary of the first printed edition of the Heptaméron).

Many facets of the Heptaméron continue to attract researchers, and, in an issue devoted to Consuming Passions, I plan to explore if and in what ways Marguerite's text can be seen as taking the side of women when her appropriated tales of adultery and cuckoldry so clearly privilege a masculinist outlook and outcome. By "appropriated" I mean those novellas that rework an earlier incarnation of the same story. Whereas the Heptaméron storytellers' agreement to "dira chascun quelque histoire qu'il aura veue ou bien oy dire à quelque homme digne de foy" (10) or their statement "Et si ne diray rien que pure verité" $(11)^{3}$ are meant to distinguish their tales from the Decameron's "fictitious" stories, the meticulous fourth volume of Le Roux de Lincy and Anatole de Montaiglon's 1880 edition of the Heptaméron leaves no doubt that virtually all of Marguerite's novellas reprise one or more printed sources that serve as the foundational element of her tales. ${ }^{4}$ The insistence on truth, as a primary rule of the game of storytelling, becomes, then, a rhetorical strategy meant to make us believe in the veracity of what will be recounted (perhaps in a tongue-in-cheek way, given the farce-like structure of the comic tales), but is also designed to beg the question of what is "pure verite."

2. Colette H. Winn, ed., Approaches to Teaching Marguerite de Navarre's Heptameron (New York: Modern Language Association of America, 2007).

3. Heptaméron, ed. Michel François (Paris: Garnier Frères, 1967). All citations will be from this edition, with page numbers indicated in parentheses after the citation. Novella 8 can be found on pp. 43-49.

4. For a compendium of sources, where sources exist, see L'Heptaméron des Nouvelles de très haute et très illustre princesse Marguerite d'Angoûleme, reine de Navarre, ed. Le Roux de Lincy and Anatole de Montaiglon (Paris: Auguste Eudes, 1880), Notes et éclaircissments, 191-336; novella 8, 231-33.

5. For the complexity of the multiple meanings of truth in the Heptaméron, see Dora E. Polachek, "Narrating the 'Truth': The Problematics of Ambiguity in the Heptaméron Prologue," Romance Languages Annual (West Lafayette: Purdue Research Foundation, 1989), 301-05. 


\section{Desires unleashed before the Heptaméron}

There is no mystery about Marguerite's intertext or intertexts for novella 8, which will be the focus of my analysis. It is clearly a variation of Enguerrand d'Oisy's thirteenth-century French fabliau Le Meunier d'Arleux. This farcelike tale of sexual trickery enjoyed immense popularity in its written and oral transmission. In the fabliau, a husband unwittingly orchestrates his own resulting state of cuckoldry. Thinking he has succeeded in gaining the consent of a young girl to sleep with him, he in fact sleeps with his wife, who, suspecting what her husband has in mind in bringing the girl home with him, complicates the situation. Unbeknownst to the husband, she changes places with the girl. Furthermore, pleased with his alleged cleverness, the husband reveals his trickery to a friend who is allowed to share in the husband's good fortune by also sleeping with the young girl, as he presumes. The husband finds himself the cause of his becoming a cuckold, without his wife ever suspecting what has occurred. The immense popularity of this story of cuckoldry turned on its head is attested to by its presence, in one form or another, in many other works. It found its way into Poggio Bracciolini’s Liber facetiarum (1438-52). Poggio's variations of the story recirculated in Guillaume Tardif's 1492 French translation, Les Facécies de Poge. A version can also be found in Philippe de Vigneulle's 1539 Cent nouvelles nouvelles. ${ }^{6}$

Even though Marguerite may have been familiar with a number of different sources, and most certainly their oral transmission in court society, it is highly likely that the anonymous fifteenth-century Cent nouvelles nouvelles served as her primary point of reference. The historical record shows that the work in manuscript form was part of the library of Marguerite's father, Charles d'Angoulême. ${ }^{7}$ And as early as 1486 the manuscript found its way into print form, increasing its popularity.

6. Le Roux de Lincy and Anatole de Montaiglon, ed., 231-33.

7. Le Roux de Lincy and Anatole de Montaiglon, ed., 3:222; the inventory of books is found under novella 47; also cited by Nicole Cazauran, L’Heptaméron de Marguerite de Navarre (Paris: SEDES-CDU, 1976), 35. 


\section{Reworking Cent nouvelles nouvelles 9}

Whatever the time period, literature shows us that consuming passions, oftentimes tragic, can also be the subject of laughing matters. In this analysis, I shall be examining how the fifteenth-century Cent nouvelles nouvelles novella 9 (CNN 9), designed to be comic in nature, remains so in Marguerite de Navarre's Heptaméron but with a surprisingly different tonality, due to the difference in who is telling the story, its agenda, and what can be termed as a privileging of a female viewpoint in its defining features. The overtly masculine space of storytelling that characterizes the Cent nouvelles nouvelles is perhaps best described by Pierre Champion who offers the following insight: "Les Cent nouvelles ouvrent $[\ldots]$ une porte secrète de la maison des hommes de ce temps [...]." In other words, readers are given a privileged view on what goes on behind closed doors when men gather together for their amusement. Critics have speculated that the author of the novella in question, identified in the text as "Monseigneur," is either Louis XI or Philippe le Bon, duke of Burgundy. ${ }^{9}$ In this collection of one hundred tales, Monseigneur and the thirty-five other storytellers share one common characteristic: they are men. The absence of women among the storytellers is notable, since the subject of these libidinally-driven tales often involves women's presence: "On parle d'elles, mais elles ne paraissent pas." ${ }^{10}$ The misogynistic thrust of many of these bawdy tales is therefore not surprising, given the male agenda to amuse, oftentimes at the expense of women, with no woman present to contest, contradict, or offer a counter-example of a particular flavour of anecdote. The creation of a state of male camaraderie that occurs in the telling of these tales has been described as characteristic of "ces anecdotes que les hommes aiment raconter, le soir, au sortir d'un bon dîner, devant une cheminée où flambe un grand feu[...]." ${ }^{11}$ Sated after a filling meal, they gather together in front of a hearty fire, metonymic perhaps of the hot tales the fire's flames will inspire. That kind of camaraderie and concomitant tonality is clearly evident in novella 9 of the collection, where

8. Les Cent nouvelles nouvelles, ed. Pierre Champion (Paris: Droz 1928), xv.

9. For questions of authorship and the identification of the storytellers of the Cent nouvelles nouvelles, see Conteurs français $d u X V I^{e}$ siècle, ed. Pierre Jourda (Paris: Gallimard, 1965), xix-xx.

10. Jourda, ed., xix.

11. Jourda, ed., xix. 
a libidinally-driven husband, obsessed by his desire to sleep with his wife's "damoiselle" of the household, thinks he will finally attain what the woman has refused to grant him up to that point. ${ }^{12}$ Much to Monseigneur's satisfaction, the demoiselle has consented to sleep with him. As luck would have it (luck and coincidence being a standard narrative staple in comic literature), a great friend of the husband comes by on a visit, and after an evening of good food and drink the friend asks if there is any possibility in the village of finding someone to continue this pleasurable evening by adding some carnal delight; "pour aller courre l'aguillette" (75) is the familiar metaphor the friend uses, and which the host immediately understands. As a token of hospitality, the husband agrees to allow his visiting friend to share in the bounty, for the illicit tryst with the demoiselle has been finalized and is to take place that very night. This male alliance is designed to solidify the already close ties that unite these socially high-ranking friends. It will involve a substitution of one man with the other in the sex bed. The bed, and more specifically, the woman's body that is found there, will be the space where the men unite, thus strengthening their union in a way that is uncannily akin to the erotic bond that can be created between men through the sharing of the same woman in a pact undertaken by both. In other words, the woman brings them closer through their both having been enclosed, if not simultaneously then sequentially, in the same intimate space usually reserved for only one, but which both of them agreed to share. "Isn't that what close friends do?" is the ironic, and funny, question that this novella raises. ${ }^{13}$ However, as was the case in the Meunier d'Arleux version, unbeknownst to the husband or his friend, the wife has gotten wind of the plan. In CNN 9 the demoiselle had informed the wife of her husband's repeated attempts to sleep with her, and the two women formed an alliance of their own, wherein the wife would take the place of her demoiselle in the space reserved for adulterous male pleasure. The wife delights in having this serve as an opportunity to teach her husband a stern lesson designed to squelch his philandering proclivities. The comic reversal at the tale's end results in the husband's discovering that his carefully laid plan of sharing the demoiselle with his good friend has resulted

12. Novella 9 will be referred to throughout as CNN 9; citations are from Les Cent nouvelles nouvelles, ed. Franklin P. Sweetser (Geneva: Droz, 1966), 73-78.

13. For the male bonding that takes place through the body of women see Eve Kosofsky Sedgwick, Between Men: English Literature and Male Homosocial Desire (New York: Columbia University Press, 1985). 
in his being the cause of his own undoing. The husband's purported cleverness and generosity towards his friend ironically results in his being the agent of his own state of cuckoldry.

My analysis of novella 8 in the Heptaméron will show the subtle yet profound changes that Marguerite introduces, all the while keeping the same narrative structure and number of protagonists. I will be asking the following questions: How does she radically change the tone of the story by means of who is narrating it? And concomitantly, how does she refigure the main characters, male and female, so that a powerful male friendship not only is dissolved but becomes a perpetual reminder of loss instead of triumph? Consequently, what becomes the prime focus of the narrative from the beginning? That is, how is agency shifted, so that an adulterous and chastised male who nevertheless remains in control in CNN 9 now becomes the butt of the joke in Marguerite's version? Furthermore, what objects does novella 8 introduce to make Marguerite's feminist outcome that much more powerful? Finally, what does Marguerite's comic reworking tell us about the possibility of female pleasure, and how does her vision of this possibility differ from its medieval intertext?

As we have seen above, CNN 9's story is easy to summarize. Typical of farce, the cast of characters is small-two men and two women. The two men, one of them married, are linked by their longstanding friendship. The plot takes place in the married man's home. The comic reversal at the tale's end results in the husband's realizing after the fact that, instead of having slept with the maid, and instead of his friend's having done the same immediately after he had finished, both had slept with the man's wife. Thus the husband had orchestrated the scenario leading to his wife's adultery with his good friend, and has become, through his own doing, what no man wants to become: a cuckold.

As we begin, it will be fruitful to compare the opening sentences with Marguerite's in novella 8: in doing so, we can begin to appreciate the variety of narrative techniques she instrumentalizes from the start in order to radically transform the cast of characters and the tale's tonality.

\section{CNN 9:}

Pour continuer le propos de nouvelles histoires, comme les adventures adviennent en divers lieux et diversement, on ne doit pas taire comment nagueres ung gentil chevalier de Bourgoigne, faisant residence en ung sien chasteau, bel et fort, fourny de gens et d'artillerie, comme a seigneur de 
son estat appartenoit, devint amoureux d'une damoiselle de son hostel, voire et la premiere après madame sa femme. Et car Amours si fort le contraignoit, jamais ne savoit sa maniere sans elle; tousjours l'entretenoit, tousjours la requeroit, et bref, nul bien sans elle avoir il ne pouvoit, tant estoit il au vif feru de l'amour d'elle. ${ }^{14}$

\section{Heptaméron, novella 8:}

En la comté d'Alletz, y avoit ung homme, nommé Bornet, qui avoit espouzé une honneste femme de bien, de laquelle il aymoit l'honneur et la reputation, comme je croys que tous les mariz qui sont icy font de leurs femmes. Et combien qu'il voulust que la sienne luy gardast loyaulté, si ne vouloit-il pas que la loy fust esgalle à tous deux ; car il alla estre amoureux de sa chamberiere, auquel change il ne gaignoit que le plaisir qu'apporte quelquefois la diversité des viandes. Il avoit ung voisin, de pareille condition que luy, nommé Sandras, tabourin et cousturier ; et y avoit entre eulx telle amytié que, horsmis la femme, n'avoient rien party ensemble. (43)

As we see, "who narrates the tale?" and "what is the tale's purpose?" are questions of prime importance. In CNN 9, it is the anonymous Monseigneur who recounts the story. The tale's purported goal is to continue transmitting to his male companions new stories about the diversity of "adventures" (to be read here in the sexual sense) and how they can pop up in many shapes, forms, and places. In contrast, because of the existence of the frame narrative in the Heptaméron, novella 8's story, while seemingly identical in content, is recounted by Longarine, one of the five female devisants in the frame story. Her goal will be two-fold: she will obey the group's desire to have her tell a story that will make them laugh, but will refuse to have it be at women's expense ("si ne sera-ce pas aux despens des femmes," 43). Furthermore, the prime focus of CNN 9's first paragraph is to highlight Monseigneur's wealth, status, and power. Even though we don't know his name, he is described as gentil chevalier, and later on again as bon seigneur, bon chevalier. The text's continual reference to him as Monseigneur (fifteen times in the space of four pages), and the positive adjectives used to describe him (bon, gentil) have the effect of freeing him of any

14. Franklin P. Sweetser, ed., Les Cent nouvelles nouvelles (Geneva: Droz, 1966), 73. Henceforth, page numbers for this edition will appear in parentheses. 
blame for his pursuit of an extra-marital tryst. While "comme a seigneur de son estat appartenoit" (73) justifies what rightly belongs to someone of his stature-a magnificent chateau, men and arms at his disposal-it also implies that such a position entitles him to all that is in his power to desire. The presence of his wife is minimal, and will remain so in terms of her importance, signaled by the single reference to her here as "madame sa femme" (73), and only as it relates to the social rank of the demoiselle with whom he is smitten. Paradoxically, the wife may have a higher position than the demoiselle, but she is subordinate, both syntactically and psychologically, when it comes to the demoiselle's superiority in Monseigneur's desires. Furthermore, given the inclusion of the detail that in the household the demoiselle in question is socially second in status only to his wife, Monseigneur's narrative voice implies that such a high-ranking woman is a suitable and justifiable choice for an extra-marital tryst. Marital fidelity, then, never comes into question here, and its absence in the opening sentences omits it as an obstacle or moral dilemma. Justified, guiltless, and even entitled seem to be the best adjectives to characterize the narrator's attitude to this gentil chevalier.

With the term chevalier the narrator introduces a trope found in courtly love: that of the god of Love being the culprit. Having been struck by Amour's arrows ("tant estoit il au vif feru de l'amour d'elle"), the chevalier finds himself totally controlled by his "love" for the demoiselle. In short, CNN 9's narrator offers us a discourse of disinculpation that is not only expected in this masculine gathering of noblemen, but encouraged and seen as perfectly in keeping with the prerogatives associated with a certain social station. Concomitantly, how is a mortal to be expected to fight a god as strong as Love? Metaphorically struck down by love, the adverbs that accompany extreme behaviour (tousjours, jamais, si fort) are used to paint an image of a powerful lord who will die if he cannot possess the resisting maiden: "Et qui a ceste heure l'oyst, mieulx luy vauldroit la mort que sans prochain remede vivre en ce monde!" (74). How after all, can you control an unbearable urge that comes from above?

Aware of how social class can empower a protagonist and justify certain actions that would earn him disapproval if he were depicted as other than noble, Marguerite's reworking, through the voice of Longarine, immediately strips the man of his nobility (he becomes a tradesman now). She brings him down a notch further by giving him a name, and a pejorative one at that: Bornet 
(simple, stubborn, narrow-minded, blind, out of bounds). ${ }^{15}$ Since social class can no longer be used to justify Bornet's desire and since lovesickness is not a credible trope for a couturier or a drummer (except to elicit laughter), how are we supposed to understand what drives him? In explicit but metaphorical terms, Longarine the narrator provides us with an answer: for Bornet (and anyone like him) this impermanent change of partner will give him the pleasure that is gained sometimes (the adverb quelquefois and not toujours is used) by a temporary change of diet ("Le plaisir qu'apporte quelquefois la diversité des viandes"). To complicate Bornet's drive to pleasure even further, Longarine also foregrounds and centralizes the figure that is marginalized in the CNN 9 intertext: the wife. In doing so, Longarine also introduces a moral dilemma that finds no place in CNN 9: that of the double standard. In novella 8, Bornet's bond with his wife is emphasized in two ways: first, by the use of the verb épouser (nowhere to be found in CNN 9) and secondly by her being described as undeserving of being deceived: she is une honneste femme de bien, and what Bornet values is her steadfast sense of honour and the esteem in which her reputation is rightfully held by others. In other words the respect he garners from others depends to a great degree on his wife's faithfulness to him. The double standard under which he is operating is also spelled out, and qualified as unjust and illogical. Longarine goes a step further, extrapolating with a "je croy" that all the men in the assembled group at Saint Sarrance ("tous les mariz qui sont icy") value these same qualities in their wives.

Whereas most of the moralizing in the Heptaméron usually takes place in the frequently heated discussions that occur outside the space of the story, in novella 8 the female narrator gives us a more detailed analysis of what is at stake at the very beginning of her story. By underlining the serious consequences of Bornet's actions, instead of affirming men's rights to be philanderers (as was insinuated in CNN 9), Longarine indirectly derides the married male devisants listening to her tale by drawing a parallel between Bornet's double standard and theirs. Furthermore, instead of the woman in question being a suitable choice, Bornet's choice of the chambrière adds another negative character trait: he is using his position as master of the house to pressure into submission someone

15. For the importance of names as a shorthand used by Marguerite de Navarre to depict personality traits of her characters, see Colette H. Winn, "Le Clin d'oeil de l'onomaturge: les nouvelles VIII, XI et XXXVII de l'Heptaméron," Romance Notes 26.2 (1985): 149-54; for Winn's sound onomastic speculations as they relate to novella 8 , see $150-52$. 
of an inferior social class; his victim is more vulnerable because she is a servant in his household.

Just as Marguerite transforms her male protagonist's social status (from lord to tradesman), she goes a step further by robbing her protagonist of mental or physical prowess. Unlike the act of hospitality that explains the nobleman's offer to share his booty with his friend, Bornet's friendship with Sandras is laughter-inspiring from beginning to end. Whereas the gentil chevalier of CNN 9 formulates his seduction plan on his own, Bornet needs to flesh out his strategy with his tabourin/cousturier friend, with whom he shares everything "horsmis la femme" (43). Certainly part of the pleasure of this story for Marguerite's social circle, as these tales were being recounted, would have involved their knowledge of the CNN version; the detail of Bornet's sharing everything with Sandras, with the exception of his wife, creates a reader/listener-response kind of phenomenon, as they wonder how the final step-the sharing of the wifewill take place; that is, in the same way as it did in CNN 9, or with variations designed to surprise and renew the tale?

In both novellas, the male protagonist is blinded by the strength of his all-consuming carnal fantasies of conquest and triumph. We have seen how Monseigneur's mental prowess operates, whereas Bornet's is put into question. How, then, is sexual triumph inflated in CNN 9 and consequently punctured in Marguerite's novella 8 ? Succeeding in having intercourse with the woman in the bed to which they have arranged to go is never at issue in either story, for as the audience in each novella knows, each man, be he noble (CNN 9) or otherwise (novella 8), will attain what he has imagined-with the operative term being "imagined," since each man's belief in the woman's identity is false, the wife having traded places with the object of desire. If attaining his goal is never put into question, then how does Marguerite transform Monseigneur's success into Bornet's multi-faceted mess? As David Laguardia has so perceptively noted in his 2008 study of intertextual masculinity, early modern cuckold literature written by men covers up masculine worries about sexual performance by engaging in a discursive practice that stresses a man's "hyperbolic potency," particularly reassuring to an audience of other men. ${ }^{16}$

16. David Laguardia, Intertextual Masculinity in French Renaissance Literature: Rabelais, Brantôme and the Cent nouvelles nouvelles (Aldershot: Ashgate, 2008), 186; as I have noted, "hyperbolic potency" is the apt term that Laguardia has coined. 
This is, after all, how homosocial bonding takes place when the object to be penetrated-the woman-is the source of performance anxiety. ${ }^{17}$ In CNN 9 , the lord's sexual vigour is never put into question by the male storyteller. Not surprisingly, CNN 9 devotes close to half of its narrative space to the hyperbolic potency to which we have just alluded. In CNN 9 we find a minute, voyeuristic description of Monseigneur's and his friend's preparation for and accomplishment of their upstanding sexual feat. More specifically, sexual prowess is detailed in quantitative terms. After having assured himself that enough time had passed for Madame to have fallen asleep, the husband gets into bed next to the woman he assumes is the maid. As the omniscient narrative voice of Monseigneur tells us, "Il n'y eut gueres esté sans faire son devoir; et si tres bien s'i acquitta que les trois, les quatre foiz gueres ne luy cousterent, que madame print bien en gré [...] " (76).

The restrictive adverbial construction ne ... guère serves as an assurance to the male audience, since fear, often a damper to male sexual performance success, has no place here. Monseigneur is able to prove himself immediately, and just as effortlessly ("gueres ne luy cousterent") is up to proving his masculine prowess three or four times more, and in quick succession yet! This gentil chevalier then gives the signal to his friend to take his place, and to be quick about it. As for the friend's performance: “[...] si monseigneur avait bien besoigné, voire et a haste encore fist il mieulx dont madame nest pas un peu emerveillée [...]" (76). The friend is not only up to the task, but as is the case in any competitive sport, he even outdoes Monseigneur in both speed and numbers. This game ("exercice") pleases Monseigneur so much that he comes back, as potent as ever. One counts at least twelve acts of sexual intercourse in quick succession, first by the husband, then by the husband's friend, and then once again by the even more intensely aroused husband who returns to the bed.

To my mind, this scene of sexual prowess is akin to a military maneuver ("exercice" can be construed in this sense, also), reinforced by terms such as "le jour des armes assignées" (74), "de sa robe se desarme" (76), "et de plus

17. For the anxiety about impotency see Patricia Parker, "Gender Ideology, Gender Change: The Case of Marie Germain," Critical Inquiry, 19.2 (1993): 337-64; and Dora E. Polachek, "Montaigne and Imagination: The Dynamics of Power and Control," in Le Parcours des Essais: Montaigne 1588-1988, ed. Marcel Tetel and G. Mallary Masters (Paris: Aux Amateurs de Livres, 1989), 135-45, in particular 141-43; see also Ambroise Paré, “Des Noueurs d'esguillette," in Des Monstres et prodiges, ed. Jean Céard (Geneva: Droz, 1971), 100. 
belle aux armes se ratoille" (76). Taken a step further, this scene of hyperbolic potency is akin to the kind of violence that takes place in a gang rape, where speed is of the essence, and where the "gentilhommes" involved serve more as a relay team of battering rams than affectionate lovers. In this narrative of obviously phantasmagorical male sexual potency, there is nevertheless space allotted for the woman's pleasure, albeit as imagined by the male narrator. Besides the adjective "esmerveillée," the term "bel passetemps" (76) is linked to the sentence describing the wife as being no worse off for wear; instead of the agony such a night is seen to cause in other texts, the unusual quantity of sexual encounters results in Madame peacefully falling off to sleep. ${ }^{18}$

\section{Pleasure in deceit}

In Marguerite's reshaping of CNN 9's tale, male bonding no longer takes place through the ability to share the common bond that sexual potency can create between men, and if it does take place, it is very short-lived. Longarine shifts the focus to whose pleasure was greater-Bornet's or his wife's-but pleasure is taken out of the realm of the physical and catapulted into the mental through Longarine's interjection, "Je ne vous sçaurois dire lequel estoit plus aise des deux, ou luy de penser tromper sa femme, ou elle de tromper son mary" (44). Bornet's sexual pleasure is heightened by his knowing that what he is doing is against the laws of marriage, whereas the wife's pleasure derives from tricking her husband and thus short-circuiting his triumph. This triumph (which he imagines is his) is triply satisfying for Bornet: first, because he believes that it was his power of persuasion and sexual desirability that caused the chambermaid to change her mind and agree to the tryst-in-the-dark with him; second, because of the titillation derived from doing the deed under the very roof where his "unsuspecting" wife lies sleeping; and finally, because of the heightened pleasure that derives from the camaraderie that is created with Sandras. When Bornet finishes sleeping with the "maid," he regales his friend in the following manner: "Et luy feit la feste d'avoir trouvé la meilleure robbe qu'il avoit point veue" (44). Bornet is clearly bragging about what has just transpired; not only is this his veiled way of boasting about his sexual prowess,

18. For a more realistic depiction of the consequences of such a night of sexual battering (the woman dies), see Brantôme's variation on such a scene in Recueil des dames, "Sur les dames qui font l'amour et leurs maris cocus," ed. Etienne Vaucheret (Paris: Gallimard, 1991), 259. 
but it also serves to heighten the sexual arousal of Sandras, for he has been promised the next round. Once again, Longarine's narrative voice intervenes, directly before Bornet makes his pronouncement to Sandras. Unlike the narrator in CNN 9, Longarine contradicts what Bornet would like his friend to believe: that Bornet's performance smacked of hyperbolic potency. Unlike Monseigneur's swift rounds in quick succession in CNN 9, Bornet was quick for another reason. As Longarine puts it, "Et quant il eut demouré avec elle, non selon son vouloir, mais selon sa puissance, qui sentoit le viel marié, s'en alla hors de la maison [...]" (44). Marguerite's text allows us to see the self-delusion the deceiving Bornet is living under. The deflation of male ego takes place in at least two ways here: if this is the best sexual stimulant he has ever experienced, why is his performance so weak? Of course, this begs the bigger question: what is his typical sexual performance like, if he considers this his best? Adding to the comic, there is also the metaphorical use of language at work here: "qu'il avoit point veue" (44)-meant to be taken by his friend Sandras as the best that he had ever seen, but to the listener it is taken as "that he had never seen" (since, of course, Bornet's superlatives are describing his very own wife; he is totally in the dark about what has just happened).

Unlike the two friends in CNN 9, Bornet and Sandras are not evenly matched in their sexual capacities, and therefore novella 8 will not have that reassuring quality that CNN 9 is intended to have to an audience of male listeners. As director and writer Peter Cohen's 2000 film Whipped makes clear, a male's greatest fear is to be found sexually wanting when compared to his male friends. The film posits that female fidelity is so important to males because otherwise women will be able to make comparisons, and these comparisons inevitably lead to the dissolution of the friendships of the males involved since the woman now knows about the sexual peculiarities and deficiencies that no male would want to share with his other male friends. The film, then, shows how hyperbolic potency anxiety persists even now. Returning to novella 8 , since compared to Bornet Sandras is "beaucoup plus jeune et plus fort que luy" (44), what transpires as he replaces Bornet will signal difference. The wife who will be able to experience both "lovers" will be able to marvel not only at the unusual nature of this night, but will, unwittingly, be able to compare her husband's performance to Sandras's.

Longarine tells us that Bornet's wife "avoit renoncé à l'auctorité de commander, pour le plaisir de servir [...] et receut son mary non comme femme, 
mais faignant la contenance d'une fille estonnée, si bien que son mary ne s'en apparceut poinct" (44). Stepping out of her role as compliant, sexually nonjudgmental wife, in her performance as innocent maid she is now able to assess her husband's execution of his duties in bed, expressed through Longarine's choice of narrative words ("qui sentoit le viel marie"). The text gives voice to a thought that no obedient wife would have the right to articulate, but with the wife's transformation into naïve and astonished maiden, as we have seen, the female narrator can describe what the husband's performance has been like. It is clear that there is not much that is libidinally satisfying for the woman in the above encounter. But novella 8 does open the possibility for describing the woman's sexual pleasure with the introduction of Sandras, Bornet's companion, who is defined, as we have seen, as younger and more vigorous as a result. As the narrator tells us, "Il y demoura bien plus longuement que non pas le mary; dont la femme s'esmerveilla fort car elle n'avoit poinct accoustumé d'avoir telles nuictées" (44-45). Even though Marguerite may be borrowing CNN 9's "émerveillee," there is no mention of "bel passetemps", nor is there the falling off to sleep which would imply passivity and acceptance and satisfaction.

We see then another important reshaping of the tale: in Longarine's retelling there is much less of the hint in the direction of female sexual satisfaction that seems to be present in CNN 9. Instead, in Marguerite's novella 8 the wife's pleasure is more cerebral; she is portrayed as distancing herself from the act (amusing and surprising at best) as she mentally moves forward in time-from the act to her intended use of it. Her enjoyment of what just took place during this unusual night derives from what she envisions as her next step. “[...] toutesfoys, elle eut patience, se reconfortant aux propos qu'elle avoit deliberé de luy tenir le lendemain, et à la mocquerie qu’elle lui feroit recepvoir" (45). More preoccupied with the lesson she plans to preach to him than with the physical pleasure at hand, she will purposefully pay witness to her husband's failure as a faithful husband, and unwittingly will make him aware of his lack of what it takes to be a satisfying lover (she of course does not realize that the second, more unusual, and stronger and longer sexual encounter was with another man).

The central object that will testify to Bornet's failure as a husband and inferiority as a lover will be the same: the ring which Sandras has playfully removed from the wife's finger as he is about to take leave of her. As both men rest together after their night with the "maid," the ring that is now on Sandras's 
finger suggests that the bond between them has been taken to another level-that they are kin now, since they have shared the same woman. But Bornet's shock at seeing his wife's ring on his friend's finger ("fut fort estonné; et commencea à donner de la teste contre la muraille," 45) leads to the confrontation with his wife. Whereas in CNN 9 Madame castigated her husband in a tirade of seven lines, Bornet's wife's position of power is evidenced by a lesson she preaches to him that is more than four times that length. The ring, symbol of fidelity, proves to the wife her husband's violation of God's law; with her religious vocabulary she introduces the need for repentance (nowhere present in the CNN 9 intertext) and the need for reigning in his bestial desires. As she puts it, "[...] c'est le peché infame de la villaine concupissence qui brusle vostre cueur, et vous rend tous les sens si hebestéz, que par la fureur en quoy vous mectoit l'amour de ceste chamberiere, je croy que vous eussiez prins une chevre coiffée pour une belle fille" (46). For the husband the ring represents a triple loss: first, it proves that his wife is no longer the pillar of purity in which he has always taken pride; second, it signals the end of the closest friendship he had with a male friend; and third, through his wife's words, he can no longer falsely pride himself on his sexual prowess. The ring is proof positive of what can no longer remain a secret: his wife is now capable of making comparisons. Thinking it was her husband the first and second time, she berates Bornet in the following way: "car, à la premiere fois que vous y estes venu coucher, je vous ay jugé tant amoureux d'elle qu'il n'estoit possible de plus. Mais après que vous fustes sailly dehors et puis encore retourné, sembloit que vous fussiez ung diable sans ordre ne mesure" (46).

As Pierre Jourda noted in his 1930 study, and as many others have later echoed, borrowing is significantly different from copying. ${ }^{19}$ Jourda makes clear his evaluation of the material Marguerite had to work with in taking up tales from the Cent nouvelles nouvelles, which he characterizes as being filled with "sous-entendus grivois, [...] invraisemblances grossières, [...] obscénités, [...] destin[és] à flatter les plus bas instincts [...]." ${ }^{20}$ For Jourda, because of Marguerite's "finesse de touche dans l'analyse des sentiments, discrétion dans le choix des termes $[\ldots]$ et connaissance du cœur humain," her reworkings result

19. Pierre Jourda, Marguerite d'Angoulême, Duchesse d'Alençon, Reine de Navarre (1492-1549). Étude biographique et littéraire (Paris: Champion, 1930), 2:733.

20. Jourda, Marguerite d'Angoulême 2:734. 
in the creation of a different story. In short, "Elle emprunte un sujet, si l'on veut; elle ne copie pas." ${ }^{21}$ As we have seen in her re-figuration of CNN 9, Marguerite reshapes her medieval intertext and proves that the same story, when it is narrated by a woman's voice, results in a new creation that at the very least shows us what is at stake in a discourse of hyperbolic potency, and what can be done with this discourse when it finds itself in the hands of a woman writer. 